\title{
On the Political Economy of Solar Radiation Management
}

\author{
Konrad K. Ott* \\ Department of Philosophy, Christian-Albrechts-Universität zu Kiel, Kiel, Germany
}

The paper investigates what kind of economic system would favor research and deployment of Solar Radiation Management (SRM), especially sulfur based stratospheric aerosol injection (SAI). The political economy argument combines moral, economic, and political assumptions in order to reach a credible "fitting"-judgement. After presenting some normative ideas on climate ethics, the concept of political economy (PE) is explained. Variants of capitalism are distinguished. These considerations are substantiated by investigating the relation between the U.S. economic system and recent support for SRM, especially for SAI. The paper concludes that the U.S. economic system has strong affinities to SRM supported by an emerging agency network that tries to establish a pro-SRM narrative and launch SAl research initiatives. There is recent evidence that SRM has found support from policy makers. To supporters of "green" variants of capitalism, the main claims of the article provide reasons against SAI-research. The article finishes with some remarks why SAI-research should be conditional.

OPEN ACCESS

Edited by:

William C. Burns,

American University, United States

Reviewed by:

Keling Zhang,

Cristal, United States

Mikael Philip Hildén,

Finnish Environment Institute (SYKE),

Finland

*Correspondence:

Konrad K. Ott

ott@philsem.uni-kiel.de

Specialty section:

This article was submitted to Interdisciplinary Climate Studies,

a section of the journal

Frontiers in Environmental Science

Received: 24 January 2018

Accepted: 14 May 2018

Published: 01 June 2018

Citation:

Ott KK (2018) On the Political

Economy of Solar Radiation

Management

Front. Environ. Sci. 6:43.

doi: 10.3389/fenvs.2018.00043
Keywords: climate ethics, political economy, solar radiation management, stratospheric aerosol injection, capitalism, agency networks, U.S.

\section{INTRODUCTION: OUTLOOK ON STRUCTURE AND CONTENT OF THE ARGUMENT}

The recent discourse on the ethical aspects of solar radiation management (SRM), especially regarding the possible injection of sulfur-based aerosols (SAI) into the stratosphere, has resulted in a comprehensive mapping of pro- and contra-arguments which is open for further detailed analysis and discourse (see contributions in Rickels et al., 2011; Preston, 2012, 2016; Morrow and Svoboda, 2016; Svoboda, 2016). SAI belongs to the small set of SRM options that have a fast effect on global temperatures (Zhang et al., 2015). Compared to cloud brightening and space-based options to dim sunlight, SAI seems the most feasible SRM-technology. SAI is at the core of SRM. If so, it seems appropriate to speak of "SRM/SAI"-discourse. On the pro side of the SRM/SAI discourse, we find "lesser-evil" arguments, "buying-time" arguments, and "arming-the-future" arguments. On the contra side of this map, we find "hazard" arguments of different kinds, "moral-corruption" arguments and "hubris" arguments. Crucial for discourse is the question whether a trade-off ${ }^{1}$ between SAI and mitigation of GHG is likely (Hale, 2012; Lin, 2013; Morrow, 2014; Baatz, 2016). In this article, I wish to provide an outlook on how an argument on the political economy (PE) of SAI might be conceived which is to be located on the contra side of discourse. As we will see throughout this article, such arguments are, on the surface, quite simplistic arguments because they point to economic interests; yet, on reflection, they raise fundamental ethical, political, and economic problems.

\footnotetext{
${ }^{1}$ The "trade-off" problem has been often dubbed "moral-hazard-problem". Hale (2012) has distinguished at least nine variants of moral-hazard arguments against climate engineering. I follow Baatz's terminology.
} 
Arguments from moral corruption ask what kind of people would go for SRM/SAI (Gardiner, 2012). Such virtue-ethical argument refers to individual moral character traits. PE arguments ask similar but distinct questions: Are there affinities between economic structures and technologies? Does a specific technology "fit" into a given economic structure? And, more specifically, what kind of economic systems would favor research, development and deployment (RDD) of SRM and SAI? How would such RDD-strategies affect different economic systems and branches for better or worse? Such PE arguments are not prominent in fields of applied ethics because they rest on many contested premises and they always come close to heated political debates. If philosophical ethics presupposes the ideals of moral purity and epistemological parsimony, PE arguments can't take off. Under such ideals, however, one may overlook "real world" motives. Ethical scrutiny itself, then, may overlook rough forces, (hidden) agendas, (vested) interests, and narrow-minded motives.

The PE argument starts from the following consideration: Imagine that a technological innovation combats negative external effects of a given economic system onto the environment without addressing the root causes. Suppose that without technological innovations there would be an increasing pressure to specific economic systems to undergo substantial reforms in crucial branches and business models. Imagine further, that a specific technological innovation fits well into the overall performance ("culture") of a specific economic system and into the mindsets of ruling academic, economic, and political elites. Thus, such innovation is promising for such elites because it combats external effects in a way that permits the economic system to continue without deep reforms. The technological innovation is convenient or even attractive to the system's overall performance ("business as usual"). This "fitting"relation explains why such innovation may look innovative from a technological perspective, while it looks conservative and protective from a PE perspective. Note, that PE judgments on "fitting" are judgements of prudence. If one argues that "a fits to b" one can, at its best, claim degrees of plausibility. As we know since Aristotle, a logical proof is out of reach in such cases. In specific instances, such presumptive "fitting"relation can be analyzed from two angles. One can analyze, first, how technological innovations might give support to the continuity and viability of the economic system, but one can also perform social research how technological options find support by agency networks within the economic system. The first analysis is political economy proper, while the second is sociological discourse and network analysis (Sikka, 2012, 2013). Both types of analysis are given in section A Critical Look at the U.S. and Agency Networks and Narratives in the U.S.

Such presumptive "fitting"-relation allows for the following positions: A person may, first, support the economic system for the overall prosperity it brings about. She sees technologies as value-neutral means to reduce external effects. This assumption implies that promising technological options should be researched without delay. Such research should be unconditional. This person would not be troubled by a "fitting"relation. Let us dub this position "enthusiastic." A person may, second, support the economic system but recognize that the technology at stake entails risks, presumptive externalities, uncertainties, and (moral) hazards. This person must weigh the benefits of an unreformed economic system with both a) the costs of reforms and b) the overall hazards of the technology. Let us dub this position "cautious." This "cautious" position can slip into a "tragic" position, if the costs of substantial reforms are perceived as highly burdensome to companies and consumers. If such reforms are perceived to be unfeasible, technology must substitute reforms ${ }^{2}$. Another person may, third, dislike the economic system for reasons that are independent from specific technologies. She may reject high inequality, negative environmental impacts, and views technologies-with all its hazards-as devices (assets) in a portfolio of means to make the economic system run further on. Let us dub this position "adverse." Finally, a person rejects the economic system for reasons that are independent from technologies and rejects technologies for reasons that are independent from the economic system. To her, the fitting connects two evils supporting each other. Let us dub this position "rejective" 3 . The article wishes to specify this abstract scheme of thought.

The article is structured as follows: Next section presents some normative ideas on climate ethics (section On Climate Ethics 2). In the subsequent section, the concept of political economy is explained and different variants of capitalism are introduced (section Variants of Capitalism and Investment Strategies). Section A Critical Look at the U.S. substantiates the abstract conjunctive relation between economic systems and technological innovation with the relation between SAI as an instance of technology and the U.S. as an instance of a specific variant of capitalism. Section Agency Networks and Narratives in the U.S. looks at agency networks within the U.S. supporting this conjunction either enthusiastically or cautiously. Section Agency Networks and Narratives in the U.S. also comments on recent developments within U.S. policies and reflects them from an EU-perspective. Section Conclusion and Outlook concludes and argues for conditionality of SAI-field-testing.

\section{ON CLIMATE ETHICS}

\section{Strategies to Combat Impacts of Climate Change}

$\mathrm{PE}$ arguments are embedded in the overall discourse of how to address climate change and its impacts. Given the robust picture of a warming world due to still rising anthropogenic GHG-emissions, there are strong economic ${ }^{4}$, moral, and political

\footnotetext{
${ }^{2}$ Note that enthusiastic and cautious person interpret the " $\&$ " in "R\&D" differently. While enthusiasts read it as a 'first research, then deployment' relation, cautious persons claim that there should be no automatism between research and development.

${ }^{3}$ This position has been adopted by Gunderson et al. (2018) relying on Critical Theory, especially on the writings of Herbert Marcuse.

${ }^{4}$ Crucial for determining the efficient ("optimal") climate pathway is the rate of discount and other value-lade assumptions in economic models. If the rate of discount is set close to zero, if the additional utility of future commodities is set low, and if the infinite-living-agent-model is replaced by an overlapping-generationmodel, then there are even stronger economic reasons to combat the impacts of
} 
reasons to combat the many impacts of climate change without further delay. There are only four strategies to do so which, of course, might be combined to form specific political-economic pathways:

1. Aggressive and far-reaching mitigation (abatement) of GHGemissions

2. Adaptation to a warming climate

3. Carbon Dioxide Removal (CDR) on a global scale ${ }^{5}$

4. SRM, especially SAI.

Basic strategies are not exclusive, but can be combined. This set or portfolio of strategies (see Figure 1) has to be arranged in a way that gives priority to specific options. Morrow (2014) has argued that political decisions on the portfolio mix are likely to be influenced by biases and failures of different kind. Even if one speculates on perfectly balanced ("ideal", "optimal”) combinations, one has to prioritize ${ }^{6}$. Any priority must rely on some betterness-relation. All judgments on priorities should suppose assumptions on how single strategies influence each other in a dynamic international political field over time. For instance, do prospects for SAI undermine mitigation efforts ("trade-off-hypothesis"), or is SAI, as the cautious position (section Introduction: Outlook on Structure and Content of the Argument) might suggest, nothing but a short-term "add on" within a long process of curbing global emissions? Might SAI be just a prudent strategy to buy time? The trade-off-hypothesis ("moral hazard") is crucial for the PE argument. It assumes that SAI-research may undermine mitigation efforts. If one goes for SAI and aggressive and far-reaching mitigation will not take place, SAI is a route of no return ${ }^{7}$. Meanwhile, there is some

climate change by means of mitigation. The problem of discounting is crucial in Stern (2007).

${ }^{5}$ The article addresses the political economy of SRM, especially SAI. To what extent the results hold true for certain CDR technologies is to be addressed in future work. ${ }^{6}$ It is beyond the scope of this article to reflect upon the many economic studies on an "optimal" portfolio.

${ }^{7}$ In consequence, future generations may face the so called "termination problem." For an ethical analysis, see Ott (2012a). evidence that this trade-off hypothesis between mitigation and SAI is likely (Lin, 2013; Baatz, 2016). As Muraca and Neuber (2017) point out this is highly likely in growth-based economies.

The most promising pro-SAI arguments are the "arming-thefuture"-argument, the "emergency"-argument and the "buyingtime"-argument. The "arming-the-future-argument" has been critically reflected by Gardiner (2010). The "emergency"argument has been refused by Sillmann et al. (2015). The "buying-time"-argument has been analyzed in detail by Neuber (2017), showing that it is uncertain whether SAI will be phased out after some short period of "peak shaving." The "buyingtime"-argument rest on the assumption that mitigation will be intensified in this "peak-shaving"-strategy. The "buying-time"argument rejects the idea that SAI could offset emissions and conceives SAI as a limited add-on within a long-term mitigation process. From the moral point of view, "buying-time"/"peakshaving"-strategies look desirable if they are performed with the intention to protect poor people in the Global South against the impacts of climate change. The "buying-time"-argument requires starting research on SAI immediately, including smallscale field experiments that may prepare for large-scale field tests. What looks attractive from the moral point of view, might be entrenched in self-interested politics. As Horton and Keith (2016) argue, SAI deployment is legitimate even if it will be undertaken out of national self-interest as far as its global side effects benefit the poor. This, however, ignites the question of trustworthiness: Why should one believe that a high-emission state that launches SAI out of self-interest might be willing to curb emissions aggressively and phase out SAI right in time. The problem of trustworthiness refers to the problem of conditionality (section Conclusion and Outlook).

Let's take a closer look at SAI. From a technological perspective, SAI is a tempting option for advanced industrial systems since its deployment requires "big" scientific RDD, data mining, chemistry, aircraft, monitoring, securitization, governance schemes, and the like. This is true also for all patents on such technologies (Chavez, 2014). SAI would spur new business models. There would be "winners" if priority would

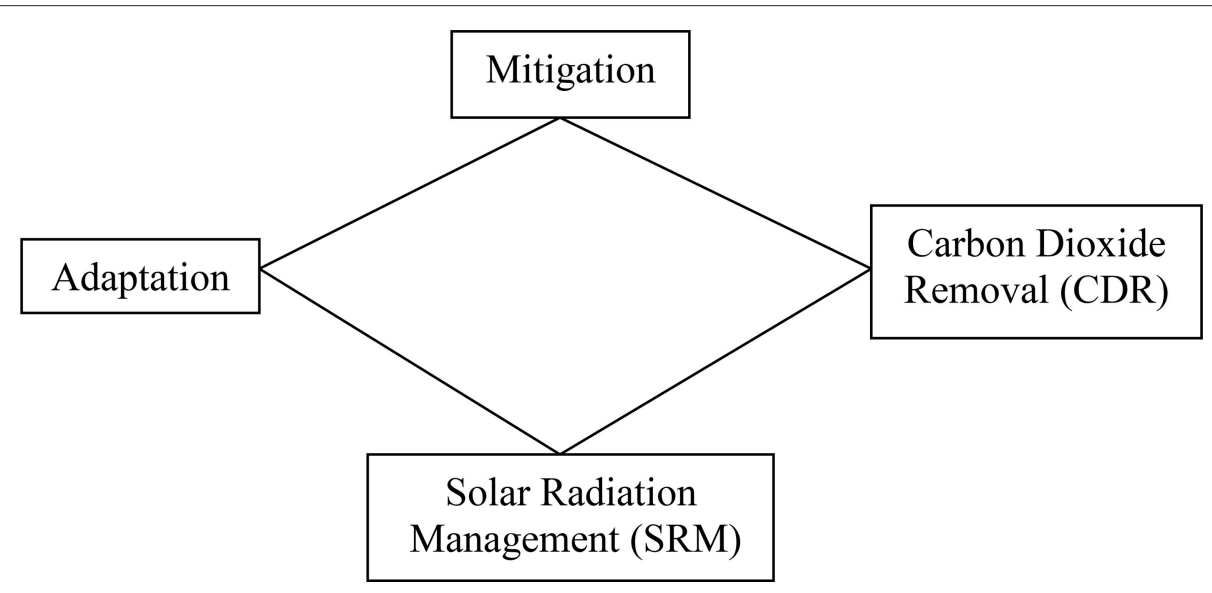

FIGURE 1 | Trapeze of strategies to respond to anthropogenic climate change. 
be given to SAI instead of aggressive mitigation. Investing in large SAI-infrastructure would be profitable to some branches, including science.

SAI is often said to be feasible at low deployment costs. Ferraro (2013, p 5) calculates the annual costs for delivering five $\mathrm{Tg}$ of aerosol to an altitude of $20-30 \mathrm{~km}$ using aircraft in the range between two and eight billion dollars. Keith (2000) argues that the costs of SAI-deployment are "trivial" compared to costs of mitigation. Recent estimates, however, pointing to analogies to other large-scale project arguing that costs are often widely underrated (Reynolds et al., 2016) and increase largely as the project proceeds and has passed its "points of no return." Klepper and Rickels (2012) and Moriyama et al. (2016) have casted serious doubts on the economic reliability of the cost estimates. Nevertheless, there is still widespread agreement in conventional economics that efficiency speaks in favor of SAI over aggressive mitigation.

From a PE perspective, however, conventional cost-benefitanalysis (CBA) should be regarded as being part of the problem. There are three reasons for this: First, only deployment costs of SAI are compared to opportunity costs of mitigation. Other costs are often neglected. In standard versions of CBA there are, second, many value-judgments entailed by specific rates of discount, the elasticity of substitution, the value of a statistical life, the infinite-living-agent-models, the KaldorHicks-compensation-test, the non-satiation axiom, the marginal value of future units of consumption and the like. It has been argued often that climate policies should not rely on CBA which are based on such morally contested assumptions (see e.g., Randall, 2002; Schröder et al., 2002; Hampicke, 2011). Most opportunity costs of mitigation are, third, nothing but delays of GDP-growth. Thus, there is a trade-off between delay in GDP growth and the risks of SAI. Proponents of SAI are often supporters of GDP growth (Sikka, 2012; Muraca and Neuber, 2017). Through a PE perspective, all three assumptions underlying CBA should be seen with a critical eye.

\section{Contraction and Convergence}

It seems fair to readers to make explicit the climate ethical stance of the author (overview Ott, 2011). Together with Christian Baatz, I have argued elsewhere that mitigation of GHG deserves priority since it addresses the root cause of the problem (Baatz and Ott, 2016) ${ }^{8}$. We argue that addressing the root cause of climate change much better serves the interests of posterity than curing the symptoms with high-risk strategies under a tradeoff against mitigation. There is a moral obligation to avoid possible future dilemmas between either continuing SAI even at highly negative consequences or stopping SAI and causing rapid climate change in an unmitigated world (Ott, 2012a). This "termination-shock"-argument remains of relevance even with respect to the (political) uncertainties of a "buying-time"strategy. As Reynolds et al. (2016) argue, SAI can't be stopped

\footnotetext{
${ }^{8}$ The "root cause" assumption allows for further claims on "ultimate" causes, as population growth, energy demand etc. The "root cause" assumptions only establishes a causal nexus between GHG emissions and climate change. Here, I follow Huttunen et al. (2015, p. 22).
}

suddenly, but must be phased out "over a long period of time." Which governance schemes may insure humanity against a termination shock? What, if some nations wish to continue SAI while others would like to phase it out? What, if a large volcano eruption happens while SAI is under full deployment? Would such situation of additional cooling be manageable? Thus, an outlook of presumptive future dilemmas makes sense even under a "peak-shaving"-scenario.

Moreover, I support "Contraction and Convergence" (C\&C) as a general strategic concept (Meyer, 2000; see also Baatz and Ott, 2017 for a detailed analysis) which, however, must be augmented by adaptation strategies. Contraction should keep GHG-concentrations with high probability within a tolerable limit. This tolerable window should be specified by the "well below $2{ }^{\circ} \mathrm{C}$ "-target compared to preindustrial global mean temperature. Such contraction implies scarcity of the remaining cumulative global emission budget $(<1.000 \mathrm{Gt})$. An egalitarian per-capita criterion can be defended as a non-ideal but feasible concept that would be fairer to the poor than the present situation of open access. This concept is highly beneficial to the world's poor although it doesn't permit developing countries to emit GHG without constraints in order to reduce severe poverty, as Shue (2014) and Moellendorf (2014) propose. Under C\&C, all relevant economic systems, including the BRIICS-states, must start to curb their emission profiles, say, to roughly two tons per person and year. Moreover, rich nations should assist poor ones to adapt to climate change via payments into a global adaptation fund. There should be, of course, forerunners among the rich states, but eventually all nations (except, perhaps, LDCs) should be integrated in a robust global mitigation regime.

Prospects for such regime are uncertain after Paris. The probability to limit global warming within a tolerable window is dwindling. The hopes for negative emissions (BECCS) shift the risks to future generations that have to cope with the tradeoffs between biomass production on the one hand, and food production, freshwater supply, and nature conservation (Bonsch et al., 2016; Creutzig, 2016). It remains uncertain how close or far the peak of global emissions might be and whether there will be a steep decline or a long-lasting high plateau of emissions. Compliance with the Paris treaty remains shaky. As we shall see in more detail, SAI-strategies are influential in states whose representatives refused to join international protocols on mandatory GHG-reduction or, meanwhile, have declared to step out of the Paris treaty (section A Critical Look at the U.S., The Climate Political Performance of the U.S.).

\section{VARIANTS OF CAPITALISM AND INVESTMENT STRATEGIES \\ Some Ideas on Political Economy}

Political economy, as understood here, is not "pure economics" as to be found in ("neoclassical") microeconomic models. "Pure economics" is about efficient (non-wasteful) allocation of scarce means of production, aiming at discounted welfare maximization of rational agents, including societies being modeled as single (infinite-living) agents (Hodgson, 2001). The axiomatic framing 
is full of normative assumptions that are relevant for economic policies. Therefore, there are reasons to believe that all economic theory is, ultimately, political economy (Sen, 1999; Hodgson, 2001; Egan-Krieger, 2014).

The PE perspective adopted in this article stems from older schools of institutionalism, from macro-economics, and from historical approaches (Braudel, 1985; Takebayashi, 2003). Prominent U.S. examples of political economy are Lipson (1960, esp. chapter 7) and Galbraith (1967). Such approaches address cultural frames of economics (such as religion), belief systems (such as "free markets"), significance of economic measures (such as GDP), concepts of freedom (such as "preference," see Hausman, 2012) and consumption, political institutions (such as property rights), distributive effects of economic activities, tax systems, welfare state institutions, the role of elites, geopolitical aspirations, and the like. It doesn't suppose a unified global social welfare function but it assumes a globally interconnected economic system in which single persons take specific roles, positions, and offices which are more or less powerful and influential ${ }^{9}$. Moreover, it assumes the performative efficacy of economic doctrines by which the mindsets of elites are shaped (as "rational-choice"-theory and game theory in theories of action). If economic agents adopt such conceptual approaches as mindset, they become self-fulfilling prophecies. A PE perspective takes into account the specificities of economic systems in their variances, as shaped by law, history, and culture.

\section{Types of Capitalism}

The PE argument focusses on technological advanced economic systems that are in some sense, capitalistic in structure. The term "capitalism" is used as a descriptive term in order to avoid all confusions between description and moral evaluation that are so pervasive in the Marxian school of thought. The term "capital" refers to stocks that yield flows of benefits. Leaving general criticism against capitalism aside, I assume that there are different variants of contemporary capitalism. I roughly distinguish between the following variants (Max Weber's "ideal types," cf. Mommsen, 1974):

- Neoliberal or "free market" capitalism (as U.S., UK, Australia)

- State-dominated “authoritarian” capitalism (as PRC, GUS)

- Welfare-state capitalism (as Scandinavia, Netherlands)

- Corporatist welfare state capitalism (as Germany, France, Switzerland, Japan).

- Rent-seeking capitalism (as Greece, Romania, Ukraine, Nigeria).

The political constitutions of both liberal and (corporatist) welfare state capitalistic societies entail citizens' rights and representative parliamentary democracy. State-dominated capitalism can come in combination with authoritarian political regimes, including electorate systems with strong presidencies.

\footnotetext{
${ }^{9}$ Since the axiom that all persons maximize their personal utility whatever they do, is not open for empirical falsification, I do not wish to build any argument on such axiom (or its derivations). My questions are about specific advantages for specific groups of people by specific strategies.
}

If China (PRC) and Russia (GUS) are recognized as postcommunist state-controlled authoritarian capitalistic societies, all major GHG-emitters are capitalistic societies. The so-called "dirty dozen" of GHG-emitters resemble variants of capitalism. The combination of political authoritarianism with economic liberalism, as we see it in China, can generate high growth rates in combination with excessive environmental pollution and very steep increases in GHG-emissions (Economy, 2004). Meanwhile, just two states emit more than $50 \%$ of global $\mathrm{CO}_{2}$ : USA and $\mathrm{PCR}^{10}$.

In historical perspective, the long period of progress and growth after 1945 was based on cheap energy in all variants of capitalism (Pfister, 2010). There have been always strong connections between GHG-emissions, industrial production, high growth rates of GDP, welfare states, and consumerism. It is contested whether a transition toward "green" capitalism is, in principle, possible. Without further debate, such possibility is affirmed ${ }^{11}$. Beside deep cultural change, such transition requires a technological shift by which "old and dirty" industries would be replaced by smart and clean ones, realizing Schumpeter's concepts of creative destruction and innovative entrepreneurship (Schumpeter, 1942). Creative destruction within a great transformation to a carbon-low economy, however, constitutes both winners and losers within different variants of capitalism and its branches. If so, environmental reform of capitalism is not in the interest of all capital holders in all variants of capitalism equally. PE arguments do not lump all capital holders together, but point at specific interests which might differently affected by technological innovations and political transformations. A process of phasing out fossil fuels rapidly may produce many "mighty losers" whose capital stocks lose economic value. Divestment strategies may count as example. Pure efficiency calculations remain silent on how economic agents will behave in the realm of political economics. PE has to take specific branches and business models into account.

Energy-intense industries are at risk if environmental innovations would spread and diffuse around the globe quickly. This can be explained via Porter-hypothesis. According to Porterhypothesis (SRU, 2002), ambitious environmental governance pays back by long-term export gains if there is global diffusion of such governance ${ }^{12}$. Under a global mitigation program, diffusion of carbon-low technologies would influence patterns of trade. Given the trade-off between mitigation and SAI, SAI-prospects may undermine the global diffusion of low-carbon technologies and related governance schemes. If so, SAI is not neutral with respect to the diffusion of environmental regulation schemes (section An EU-Perspective in Contrast).

\footnotetext{
${ }^{10}$ Interesting enough, both states have technological traditions of weather modification and can model SAI as the next step of weather modification. See Fleming (2010).

${ }^{11}$ Many eco-Marxist scholars, however, assume the contrary. This debate is beyond the scope of this article.

${ }^{12}$ It is doubtful whether integration in a globalized economy implies a "race to the bottom" or whether "green" welfare states are a kind of an insurance against the risk of global integration without which economic globalization faces increasing domestic opposition. Thus, I do not assume that a 'race to the bottom' is unavoidable.
} 
Variants of capitalism with robust welfare-state traditions and cultures of deliberative democracy generally perform better in environmental policy-making ${ }^{13}$ Performance is low in rentseeking and authoritarian variants. From the angle of climate ethics, some sympathy for "greening" welfare-state variants seem reasonable (see also Münch, 1998).

\section{The Logic of Investment}

Capitalistic economies are based on private ownership of the means of production (stocks of capital) which must be reinvested. The general spirit of capitalism, however, is the spirit of investment (Schumpeter, 1942; Weber, [1905]/(2001)). Investment decisions fix capital for a period of time. They are framed by a political and legal order and are stimulated by incentives and by expectations on returns of investments ("profit"). Investment decisions refer to uncertain expectations about future markets, future demands, future prices, future governance schemes, and the like. Thus, they are risky, and investors usually wish to reduce risks to their capital. To managers of large capital stocks, loss of capital is to be avoided. Investments can be made in different technologies in the same branch (as a shift of investments from fossil fuels to renewable energies) or they can be shifted across branches (from car production into wellness tourism, into organic agriculture, or into biomedicine). Within highly competitive systems, shifts across different branches are risky since corporations may lack expertise in these new areas. Even if capitalism, seen at large, might be a system of creative destruction (Schumpeter, 1942), single corporations tend to be rather conservative and prefer to reinvest in their home-branch. There might be "mighty losers," fearing both loss of capital value and are risk-averse in shifting to new branches. Such agents wish to conserve existing structures and react against change. If SAI spurred new business models within such sectors, some entrepreneurs will push SAI.

Investment decisions aren't made in a vacuum but are to be made under specific boundary conditions. Many investment decisions must have a close eye on policy making. In any developed capitalist economy, there are consultations and negotiations between politicians, administrative bodies, and representatives of companies holding large stocks of capital. This is true a fortiori with respect to the energy sector since investments in energy supply schemes are policy-driven, require high up-front investments and are long-term oriented. Existing capital stocks in fossil-fuel based industries amount to trillions dollars (Chavez, 2014: 8). Aggressive mitigation programs would reduce the economic value of these capital stocks. Chavez regards this de-valuation as the real structural barriers against mitigation policies. If so, under a $\mathrm{PE}$ perspective one might expect many SAI-proponents in all these variants of capitalism, in which fossil fuel based industries are politically influential.

Present investment decisions are crucial for GHG-emissions for the coming decades. A global shift away from fossil fuels to low-carbon renewable energy supply schemes requires largescale upfront investments on a global scale. Magnitude of

${ }^{13}$ See, for example, the "Environmental Performance Index" (EPI) of Yale University: http://epi.yale.edu/. upfront-investments in low-carbon industries is roughly about some dozens billion per year over decades (WBGU, 2011: 153). The (un)likeliness of such investments depends not on general scarcity of capital but depend on the political will to channel and nudge investments into low-carbon industries. If aggressive mitigation would be the only game in the global village, investments in the energy supply will shift toward renewables. This will not guarantee reaching the "well-below- $2^{\circ}$ "-target but it may reach a low-carbon future with more promising prospects for adaptation. If wealthy states would subsidize renewable energies domestically, and would give support to international technology transfers in addition ('leap frogging'), much capital could be channeled to new low-carbon industries. Such a trajectory is still within reach.

If SAI is likely, however, such investments might be discouraged. This is an implication of the trade-off. Under SAIprospects there might be rather conventional investments in fossil fuels instead (tar sands, fracking, deep sea oil drilling, ocean floor mining of methane hydrates). In a thought experiment, one may take the role of a risk-averse holder of capital who wishes to invest a billion dollar either in renewable energies or in nonconventional fossil fuels. To such investor, SRM/SAI-prospects make a difference in prospects about returns of investment. If a rational investor believes that there is a self-stabilizing "fitting"relation between BAU of an economic system and SAI, and if she rationally believes that BAU-lobbies have far more influence on policy-makers than newcomers, and if, moreover, her mindset is supportive to the system as it runs, she has economic reasons to invest in non-conventional and/or conventional fossil fuels. If most investment decisions are made according to such reasons, capital stocks remain within fossil fuel based branches and related industries. Some investments will flow directly into SAIrelated industries. One should not extrapolate the findings in experimental economics to investment decisions: Even if lay persons in controlled economic survey show a negative tradeoff (Merk et al., 2015, 2016) it doesn't follow that investors will behave accordingly. They might try to create an influence on politics in order to keep the status quo or support politicians who campaign in favor of fossil fuels. This is a crucial point: If persons prefer mitigation over SAI in discursive and participatory settings (Bellamy et al., 2016), it doesn't follow that policy makers and economic elites will decide accordingly.

Given this, PE arguments should be observant of specific variants of capitalism. In any case, such PE arguments should be able to explain why some variants of capitalism might be more prone to SAI-trajectories than others are ${ }^{14}$. In the next section, I focus exclusively on the U.S.

\section{A CRITICAL LOOK AT THE U.S.}

It seems fair to argue that the new debate on SAI has emerged in the U.S. after Crutzen's initial paper (Crutzen, 2006). It seems also fair to say that the U.S. is to blame for their non-cooperative

\footnotetext{
${ }^{14}$ I differ from Gunderson et al. (2018) in this respect. There is no single entity as "the" capitalism, but there are highly different varieties. Such varieties can make huge differences in environmental performance and mitigation policies.
} 
behavior in international climate policy-making since the Rio summit (Shue, 2014). The U.S. has clearly failed in domestic mitigation, since it has increased its emissions since 1990. The U.S. variant of liberal market capitalism is based on high energy input, old Fordist industries, overheated consumerism with high indebtedness, fixation on high GDP-growth-rates, deregulation of financial markets, high inequality, high violent criminal rates, high budget deficits, "rust belts," and large military-industrial complexes. Aggressive mitigation is opposed by many influential actors within the U.S. political-economic system, including mass media (Kearnes, 2007). The reasons against mitigation are often backed by climate skepticism in the past (Oreskes and Conway, $2011)^{15}$, but have recently shifted to SAI (Sikka, 2012). Some remarks on the Trump administration and on recent political developments are added to this picture in section The Trump US-Administration and SAI.

\section{The Climate Political Performance of the U.S.}

The GHG-emissions have increased in the U.S. roughly $18 \%$ since 1990. They are on average roughly 21 tons per person and year. $\mathrm{CO}_{2}$ emissions were 4.8 billion tons in 1990 and 5.333 billion tons in $2011^{16}$. Even the most progressive current mitigation strategies do not reach the former Kyoto targets. Many energy investments have turned to Canadian tar sands, offshore oil drilling, and fracking. Exploration for new oil fields and geostrategic securitization of strategic supply continue. The emissions have decreased in recent years due to a shift to unconventional fossil fuels ("fracking"). This shift, however, adds a new mining activity and it does not exclude a return to conventional fossil fuels as soon as the fracking-boom will be over. This recent shift as such does not establish a structural transition to a low-carbon economy.

Despite many laudable activities in some federal states and towns, the U.S. has no strategic blueprint for a transition to low GHG-emission-profiles. Perhaps, the U.S. have missed their window of opportunity to start mitigating emissions in the 1990's and have gridlocked themselves in a situation that forces them to go for SRM/SAI. This picture would be in line with the "tragic" and "adverse" position (section Introduction: Outlook on Structure and Content of the Argument). The U.S. contributes to make the very premise true on which many SRM/SAI advocates argue: Mitigation won't be sufficient.

\section{Carter's Explanatory Scheme}

In this subsection I wish to test the hypothesis that the U.S.system has run into a specific "hazardous" trajectory since

\footnotetext{
${ }^{15}$ According to the documents in Anderson et al. (2017), the energy industries knew about the "greenhouse" effect since the 1970ies. The push for nuclear energy was justified by leading proponents, as Chauncey Starr and Merril Eisenbud, via concerns about climate change effects by burning coal.

${ }^{16}$ See http://cait2.wri.org/profile/United\%20States. According to Environmental Protection Agency (EPA) (2018), overall US GHG-emissions have increased from 6.356 million metric tons $\mathrm{CO}_{2}$-eqivalents in 1990 up to 7.351 million metric tons in 2007. They decreased to 6.511 million metric tons in 2016 due to substitution from coal to gas and to warmer winter conditions. The open question is whether the decrease is the beginning of a long downward trend or just an intermezzo.
}

decades which makes it akin to SAI. Such dynamic trajectories have been schematized by political philosopher Carter (1993, 2004). Carter distinguishes beneficial (pacifistic, egalitarian, democratic, and "green" technology) from hazardous dynamics. One of the many premises in the PE argument is Carter's assumption that there is a reinforcing and mutually stabilizing dynamics on both the beneficial and the hazardous trajectory. There can be political shifts from one dynamics to the other but such shifts require strong political movements, an electorate system that does not block new parties, and a shift in cultural hegemony of ideas. Carter's scheme is clearly both value-laden and explanatory. The positive and negative values within Carter's scheme are shared by environmentalists and by persons favoring strong sustainability, deliberative democracy, a robust welfare state, and limited inequality ${ }^{17}$. The explanatory force of the scheme, however, must hold irrespectively whether these values are shared or not. In principle, even supporters of both SAI and the U.S. ("enthusiasts") might agree that there are some structural affinities between SAI and the U.S. variant of capitalism. By hypothesis, the U.S. are taken as an instance of Carter's scheme (see Figure 2).

Let's briefly look at each point in turn (see Figure 2): The military budget of the U.S. is the highest world-wide and has sharply increased since 2003 up to 711 billion dollars in 2011 (4.8\% of GNP in 2010). The military-industrial complex, including electronic surveillance, borderline control and home defense, is strongly influential. Many brokers move between the political system and this complex, lobbying against cuts in military expenditures. This complex would clearly benefit from $\mathrm{SAI}^{18}$. Nationalistic forces, such as the Tea Party movement, the National Rifle Association and Christian movements within the Bible Belt create political influences, especially on the Republican Party. If SAI would presumably serve U.S. interests, Trump's "America first" politics should be supportive to this technology.

The GINI-coefficient is higher in the U.S. than in all other industrialized states. According to Milanovic (2016, p. 71-74), income GINI increased since 1979 after some period of decline after Second World War. Wealth GINI has increased from 0.45 in 2007 up to 0.477 in 2011. Current inequality comes close to rates at the beginning of twentieth century (Bourguignon, 2012). Inequality has increased to kinds of high-end-excessiveness of a tiny minority. There is a squeezing of the middle class in the U.S. creating fears and anxieties since there are far less welfare state securities. There are widespread resentments against immigration (Cafaro, 2015).

There are severe concerns about democratic culture. Wolin (2008) has described the political system in the U.S. as "managed democracy." The political debate on climate change is a paradigm case for such management as it has been distorted by interest

\footnotetext{
${ }^{17}$ It is clearly beyond the scope of this article to justify these concepts ethically. See, for overview, Ott (2014) with respect to strong sustainability, and Ott (2012b) with respect to Habermasian deliberative democracy. Welfare state justifications might be found, among others, in Rawls (1971) and Cohen (1989).

${ }^{18}$ Cairns (2014) points at the "dual use" character of SAI. To Cairns, it is highly likely that military bodies might carry out SAI. The prospects and pitfalls of a securitization framing are outlined in Engelke and Chiu (2016).
} 


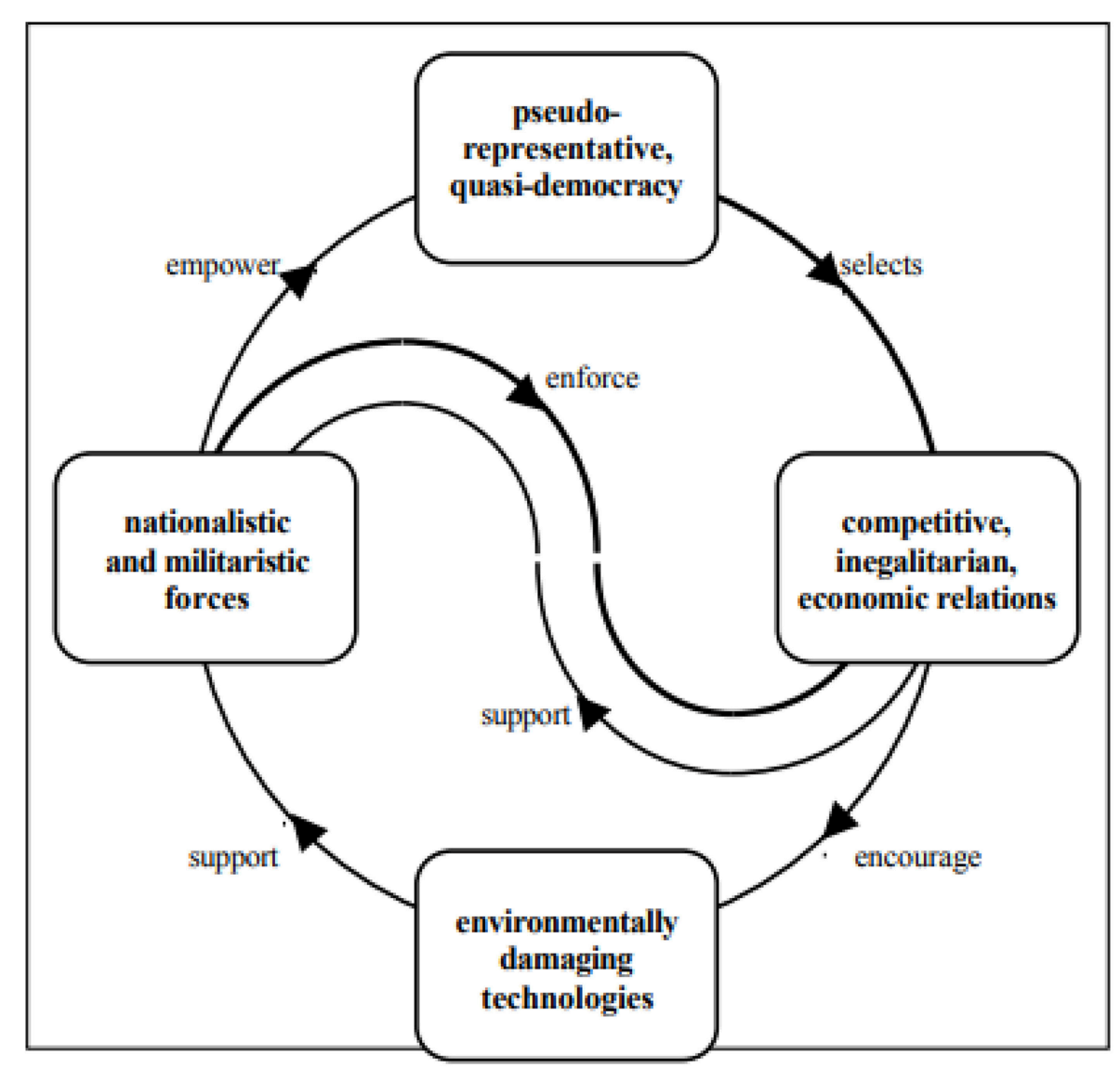

FIGURE 2 | Carter's scheme of hazardous dynamics. Figure adopted from Carter (2004), p. 316 with kind permission of White Horse Press.

groups. If one gives credit to Wolin's analysis, democracy in the U.S. is in a critical state in many respects ${ }^{19}$.

Given that the U.S. variant of capitalism well resembles three out of four poles of Carter's scheme (Figure 2), given further the arrows that point toward the pole of technologies, and given the cultural trust in engineering solutions, SAI fits coherently in the fourth field of the scheme. This is to say, that the strong support that SAI finds in the U.S. (see section Agency Networks and Narratives in the U.S.) does not come as a surprise under Carter's perspective. This result supports the "fitting"-hypothesis (section Introduction: Outlook on Structure and Content of the Argument $)^{20}$. Gunderson et al. (2018) come to the same result: SAI makes sense in a political structure that is unable to reduce emissions drastically, believes in "cheap fixes and easy ways out," and can incorporate business models that profit from RDD on SRM/SAI.

\footnotetext{
${ }^{19}$ The reader shall feel free to add some evidence from the Trump administration to Wolin's picture.

${ }^{20}$ The argument as given so far only allows for stating affinities and correlations rather than causes. To establish a strong causal nexus would require far more studies in the field of the economies in the U.S. At the moment, it must be sufficient to state affinities ("fittings") and to entertain the hypothesis that there might be a nexus. Such hypothesis shouldn't be confused with conspiracy speculations.
}

This preliminary result ignites the question whether the U.S. are a trustworthy country to launch large SAI-research programs. This question does not deny the individual liberty right of scientists to do research, but point at how such "big science" programs might be embedded in the overall structures of the U.S. economy.

\section{AGENCY NETWORKS AND NARRATIVES IN THE U.S}

\section{Between Argumentation and Ideology}

Ethical analysis of climate-engineering discourse has to reflect presuppositions and consequences of all pro- and con-arguments being made in the field. Such analysis takes arguments at face value and organizes them into maps (Betz and Cacean, 2012). It takes presumptions of moral argumentation seriously. Ethical analysis supposes that arguments are given and taken with a discursive attitude. This general attitude constitutes a common quest for soundness and substance of arguments. Ethical analysis ("reconstruction") distinguishes between a context of discovery and a context of justification. Contexts of discovery with all their accidental features have to be abstracted away as an argument is 
to be reconstructed according to its structure (premises, logic of inference, credibility of single assumptions).

These discourse-ethical presumptions seem naïve and highly idealistic in the field of politics. Within PE, a step from discourse ethics into critical discourse analysis seems necessary. From the perspective of discourse analysis, the concept of discourse refers to persuasive strategies embedded in power structures (Sikka, 2012, 2013). Such studies point at specific contexts of origins, framings, organizations, vested interests, the rhetoric of hidden agendas, science-policy-interfaces and the like ${ }^{21}$.

\section{Networks and Narratives}

Discourse analysis refers to agency-networks and to their narratives and frames (Grüne-Yanoff, 2016). If there is a pro-SAI agency-network emerging in neoliberal variants of capitalism, many of its members should hold high offices and should be actively engaged in it as professionals. We should expect those people in the military, aviation, and space-flights industries, in all industries based on fossil fuels, in conservative, and libertarian think tanks, in right-wing forces of the Republican Party and in some epistemic communities ${ }^{22}$ being involved in related research programs. Recent studies confirm this hypothesis (Sikka, 2012 , 2013). One can register the emergence of a pro-SAIagency network in recent years. Leading proponents are some epistemic communities (such as the Defense Advanced Research Projects Agency), several think tanks (as American Enterprise Institute and the Climate Response Fund), donors (such as Bill Gates and Richard Branson), corporations (such as the Aurora Flight Science Corporation), and many media agents. Meanwhile, there are debates how patent law could cope with the grab for broad patents on climate-engineering technologies (Geopool proposal, see Chavez, 2014). Huttunen et al. (2015, p. 16) present evidence from many documents that "numerous conservative, climate-skeptic think tanks and lobbyists" launch SRM/SAIfriendly reports for political and public audiences. According to Huttunen et al. (2015, p. 27), "hopes and permissive attitudes were more pronounced in the USA than elsewhere." Gunderson et al. (2018) point at the language of "techno-glorification" being used, especially on medical metaphors.

All members of this agency network propose to enlarge and intensify SAI-research. Meanwhile, David Keith is going to launch a small-scale field experiment on SAI in Arizona in $2018^{23}$. The field experiment has been announced in 2014 (Dykema et al., 2014). The rationale is to be found in Keith (2013). Keith, as his writings and talks clearly indicate, belongs to the cautious camp of SAI-supporters. Cautious proponents, as Keith, concede that the steps between modeling and laboratory research and full deployment should be governed by riskawareness and prudence. Jamieson (2014, p. 226), however, points at the political logic of large research initiatives: "They fed

\footnotetext{
${ }^{21}$ By doing so, such studies touch the problem of 'ideology' which is beyond the scope of this article.

${ }^{22}$ Hamilton (2014) takes a closer look on Lawrence Livermore National Laboratory.

${ }^{23}$ Keith rightly distinguishes between field "experiments" and field "tests." Large tests come close to deployment. The line between field experiments and field tests is fuzzy.
}

fortunes, careers, and reputations. As with the Strategic Defense Initiative, a dedicated geoengineering research program risks a self-amplifying cycle of interest groups and lobbies, building momentum toward eventual deployment as a way of justifying the research." If there are large research programs without deployment, some members of the SAI-network might see the research money as sunk costs.

Agency-networks cohere because members share common interests, values, commitments, mindsets, and attitudes. Agency networks are not only constituted by interests but also by beliefs, moral visions and guiding images ("Leitbilder") which form an affirmative narrative on matters at hand ${ }^{24}$. All agency networks long for a credible narrative of goodness, and so does SAI. SAIproponents borrow from NGO's and the IPCC's reports (IPCC, 2013) most dramatic warnings against the impacts of unmitigated climate change. It is argued that mitigation strategies are bound to fail despite Paris. This prediction is often backed by gametheoretical and neo-realistic approaches within the theory of international relations. Sikka $(2012,2013)$ mentions additional components of this narrative: (a) belief in scientifically based technological solutions ("big science"), (b) belief in market-based, efficient solutions, (c) significance of high growth rates of GDP, (d) construction of an emergency situation which allows for uncommon measures, and (e) a cultural tradition of "fixing the sky" (Fleming, 2010). Some SAI-proponents reject mitigation because "emission reductions do not provide direct control over temperature" (Bickel, quoted in Sikka, 2012: 170). More recently, moral elements have been incorporated into this narrative. Ethical pro-arguments and the elements of this narrative have large overlap. Jason Blakstock proposes to base SAI-deployment on the obligation to help poor groups in the Global South deal with impacts of unmitigated climate change (as heat waves, extreme events, droughts, and the spread of malaria). At the edge of the narrative, there are positive external effects of SAI being mentioned, as protecting children from sunburn and a reduction of skin cancer. It is easy to claim that SRM/SAI is a tragic predicament in the Anthropocene.

\section{THE TRUMP US-ADMINISTRATION AND SAI}

This PE perspective seems not confirmed by the politics of the Trump administration ${ }^{25}$. Given the "fitting"-relation (section A Critical Look at the U.S.), it looks somewhat paradoxical, that the emerging pro-SAI network still remains in some distance from the Trump administration. Donald Trump himself has been deeply influenced by climate skepticism. This is true for Scott Pruitt, too, who has been appointed chief of Environmental Protection Agency (EPA). As long as Trump denies the very existence of climate change ("Chinese hoax"), he clearly doesn't have to consider SAI as an option to combat its impacts. Former

\footnotetext{
${ }^{24}$ The "fixing the sky"-tradition may serve well as a background tradition. See Fleming (2010).

${ }^{25}$ In June 2017, Trump declared that the US would withdraw from the Paris agreement. There is a clear convergence between the interests of the fossil-fuel industries and many of Trump's voters, especially in the "rust belt."
} 
Secretary of State Rex Tillerson, former Exxon CEO, however, stated that climate change is "an engineering problem, and it has engineering solutions" (Tillerson in: Mooney, 2016). This statement refers to conventional means of adaptation (as flood walls), but it can easily be enlarged to SAI. Meanwhile, the "Committee on Science, Space, \& Technology" has had a hearing on climate engineering in 2017. In this hearing, scientist Douglas MacMartin argued for aggressive research projects which might identify the best options within 10 years and "have something" for deployment a decade later.

After this meeting, Lamar Smith launched a brief paper on climate engineering (Smith, 2017). Smith says, geoengineering "could become a tool" to curb the impacts on climate change. Smith mentions cloud brightening technologies as well as SAI. To Smith, SRM is an "intriguing idea." "Instead of forcing unworkable and costly government mandates on the American people, we should look to technology and innovation. (...) Geoengineering should be considered when discussing technological advances to protect the environment" (Smith, 2017). End of January 2018, Smith launched a more elaborated paper (Smith, 2018). One should take Smith seriously as a politically influential proponent of an enthusiastic position (as defined in section Introduction: Outlook on Structure and Content of the Argument), wishing to spur SRM/SAI on its way onto RDD. Some quotations may suffice to justify this judgement. Smith (2018) states: "Another area of research that has been overlooked for too long is geoengineering. This concept involves using technology to make positive changes in our atmosphere. While this subject is at the basic research phase, many concepts are groundbreaking and warrant further investigation. One such area of research is SRM, which involves slightly altering the amount of sunlight that penetrates and warms the earth." This rhetoric suggests that sunlight itself is an environmental problem since it "penetrates" the earth. SAI, then, could prevent the planet from such penetration by sunlight. Smith augments his way of looking at things by enthusiasm about the nexus between scientific research and private enterprise. Smith (2018): "By focusing our resources on basic research, we can find solutions that meet our needs. America is home to some of the best scientists and greatest scientific facilities in the world. Supporting our scientists with adequate resources for technology innovation will unlock ideas and concepts that can be employed by private industry." Smith contrasts technological innovation with "burdensome regulations" in a way that rises concern about a tradeoff between SAI and mitigation. Smith finalizes his statement as follows: "As in the past, by letting technology lead the way, Americans will reap the benefits and enjoy a better quality of life." Thus, the crucial messages from the geoengineering-network have meanwhile reached congress. Until now, Trump himself has remained silent on SAI. If denial of climate change can't be continued, and if Trump might become aware of SAI via Smith or other persons in the administration, he might see SAI as perfect opportunity to combine "America first!," fossil fuel reinforcement, GDP-growth, "big-science"enthusiasm, opportunities for private enterprise, support for the military-industrial complex, and support of his voters by launching SAI- research initiatives. In a lecture at EM-Tech-MIT conference in November 2017, David Keith expresses his fear that the very idea of SAI technology might be "exploited by those who wish to block emission." Keith's nightmare is a Trump tweet (Orcutt, 2017). As it seems, the cautious option to keep temporal SAI in the portfolio of means to reach a $1.5^{\circ}$-target (MacMartin et al., 2018) must be reconciled with the rather enthusiastic perspectives that may take SAI as a substitute for mitigation, as soon as SAI-initiatives are launched. Such predictable tensions at the science-policy-interface constitute high moral responsibilities for scientists being involved.

\section{An EU-Perspective in Contrast}

It is beyond the scope of this article to analyze all variants of capitalism (section The Logic of Investment) with respect to SRM and SAI. Special attention should be devoted to China (Moore et al., 2016), because China has some tradition in weather modification (Xueliang, 2009) and wishes to keep constant or even increase agricultural yields even in times of climate change. In this article, I focus on the EU, especially on Germany and France $^{26}$. For a comparative analysis of official documents in different countries, see Huttunen et al. (2015).

How, one may ask, might European variants of capitalism that undertook first steps toward "greening" the economy, are willing to phase out coal stepwise, and are investing in renewable energies be affected by presumptive large SAI research programs? SAI strategies that fit into one specific variant of capitalism may not necessarily benefit other variants. They might be detrimental to reforms. It is highly questionable whether SRM/SAI initiatives in the U.S. are in the interests of EU countries. How would, for instance, the effectiveness of photovoltaic solar energy be affected by SAI?

As Martin Jänicke has argued in his many publications (see Jänicke, 2013), there are emerging lead-markets within greening welfare state variants of capitalism. Lead-markets can be pushed forward by setting environmental standards high, regulating production by means of law, and subsidizing renewable energies for some time. Although the environmental performance of welfare state capitalism is far from perfect and GHG-emission are still far too high (roughly nine tons per person and year in Germany), there are some environmental success stories. Meanwhile, mainstreaming renewable energy supply schemes, smart technologies, and low-carbon lifestyles are on the EUagenda ${ }^{27}$. With respect to long-term investments in the energy system, some countries have found a societal agreement to shift electricity production to renewables. Despite some recent tendencies to stagnation, the German "Energiewende" can be seen as a paradigm case for such transformation (Baatz and Ott, 2016). Replacement of nuclear and coal burning facilities by renewable energies implies huge upfront investments in wind and solar power facilities, enlarged grids, regulation of biomass production, and enhanced energy storage. There must be energy-saving investments into buildings, infrastructure, and

\footnotetext{
${ }^{26}$ See for France Ministère de la Transition Ecologique et Solidaire (2017).

${ }^{27}$ The Environmental Kuznets Curve (EKC) is not an economic law but it can be made true by political practices. Thus, EKC is a prescriptive rather than a descriptive model.
} 
transport systems. Such upfront-investments in a low-carbon society make economic sense only if costs of fossil fuels increase over time. If societies would return to fossil fuels those upfront investments would be at risk. Thus, SAI affects the economic value of capital stocks unevenly. If Carter's scheme is enriched with recent debates about rebound-effects (Chitnis et al., 2013), SAI can be seen as constituting both a technological macrorebound with respect to limited natural sink capacities and an economic defense strategy against structural change. SAI is aggressive against investments in carbon-low technologies. Macro-rebounds intentionally stretch natural boundaries and cultural limits in order to make a system run longer than it otherwise would be able to ${ }^{28}$. Such rebounds are a kind of protectionist measures. Given this, RDD on SAI should be seen as a presumptive aggressive protectionist macro-rebound against change. Therefore, "greening" variants of capitalism have prudential macro-economic reasons to oppose SAI initiatives. This prudential economic perspective might be enriched with moral principles of climate ethics (section On Climate Ethics). It might be also enriched with skepticism against "arming-thefuture"-, "emergency"-, and even "buying-time"-arguments and against cost estimates of SAI (section On Climate Ethics). If so, prudential economic reasons, climate ethical reasons and specific anti-SAI-reasons are reasons to reject the enthusiastic perspective as adopted by Smith (section The Trump US-Administration and SAI).

\section{CONCLUSION AND OUTLOOK}

There are some results in both kinds of analysis: In section A Critical Look at the U.S., we identified the U.S. economic system as a variant of capitalism that has strong structural affinities to SAI (see also Gunderson et al., 2018). With help of Carter's scheme, we can propose a plausible "fitting"-judgment for further debate. In section Agency Networks and Narratives in the U.S., we identified an emerging agency network within this variant that is devoted to R\&D of SAI and that tries to establish a specific proSAI narrative. Recent development (Smith, 2017, 2018) provides strong evidence that this narrative has now reached the realm of policy making. The demon is out of the bottle.

Given the results (section Variants of Capitalism and Investment Strategies, A Critical Look at the U.S., and Agency Networks and Narratives in the U.S.), the problem of trustworthiness pops up again. Shall we trust in decency, scrutiny, and prudence of leading agents if the U.S. would launch a large SAI-initiative? Is this variant of capitalism, inclusive its SAInetwork, in a moral position to take further steps on a RDDroute which points at large field tests and, finally, deployment? In principle, this is an open question. Given the climate ethical premises (section On Climate Ethics) and the fitting-judgement, it isn't. Since (a) the U.S. do not curb their emissions sufficiently, since (b) the U.S. blocks progress in international climate negotiation (and may leave the Paris treaty), since (c) the new

\footnotetext{
${ }^{28}$ Large-scale-land-acquisitions might be another example for macro-rebounds to counter land degradation. The idea that SAI can be viewed as a macro-rebound originally belongs to Barbara Muraca (oral communication).
}

presidency refuses to pay into a global adaptation funding facility, since (d) some political leaders deny climate change against all scientific evidence, since (e) ruling elites may take SAI as substitute for mitigation as well as rebound against economic change, this country is, seen as a matter of principle, not in a moral position to launch large SAI research initiatives. While PE perspective explains why SAI fits into this variant of capitalism, climate ethical perspective looks upon such prospects reluctantly.

What can one do? There are multiple strategies against SRM/SAI-programs in the U.S. Out of this multitude of strategies I mention only two.

The first strategy would give support for the camp of cautious scientists within the U.S. system of research. I see David Keith, Douglas MacMartin, and Ken Caldeira as highrank members of the cautious camp. Members of this camp have often argued that the only responsible SAI-strategy would look like this MacMartin et al. (2018): In principle, SAI should not be taken as substitute for mitigation, but should be strictly supplementary to mitigation being the first-best strategy. The only acceptable SAI-option is temporal peak-shaving within a long-term global mitigation strategy to combat middle-term adverse effects of climate change. Such peak-shaving deployment should be intensively and open-ended researched with respect to side effects (acid rain, precipitation patterns, ozone layer etc. $)^{29}$. There must be a clearly defined and robust termination strategy. Such research process should be monitored by a board of international scientists. This strategy assumes, in principle, a deep distrust against SAI-initiatives in the U.S., but it also assumes a camp of cautious scientists whose members are willing and capable to adopt the role of concerned and responsible scientists.

The second strategy is a global political one. According to Huttunen et al. (2015, p. 28), official policy development on SRM/SAI is "still in an early stage, focusing on exploring the topic." If Huttunen et al. (2015) are correct on this ongoing "cautious exploratory phase," most governments are open-minded or even critical about SRM/SAI prospects. Many international organizations support a skeptical attitude against SRM/SAI. If there is any agreement at all in the climate engineering discourse, there is the agreement that SAI deployment would be unnecessary if mitigation efforts could keep the increase of global mean temperature within the tolerable window of "well below $2{ }^{\circ} \mathrm{C}$." In such moments of political exploration and under the general agreement just mentioned, a well-organized, campaigning global civil society could create a domestic influence on national governments to intensify mitigation efforts in order to avoid SAI. Many studies indicate that a "negative tradeoff" is widespread within civil society. When ordinary lay people are informed about SRM/SAI prospects, they prefer intensified mitigation efforts instead. This more intuitive and personal negative trade-off can be backed by climate ethics (section On Climate Ethics) and it should be politicized in the global arena. If governments would commit themselves via intended national contributions under the Paris regime to such

\footnotetext{
${ }^{29} \mathrm{~A}$ similar position has been substantiated from an economic perspective by Quaas et al. (2017). Quaas et al. (2017) suppose an "arming the future"-argument.
} 
intensified mitigation efforts, SAI might become unnecessary. It would take another article to elaborate this strategy in more detail.

\section{AUTHOR CONTRIBUTIONS}

The author confirms being the sole contributor of this work and approved it for publication.

\section{REFERENCES}

Anderson, D., Kasper, M., and Pomerantz, D. (2017). Utilities Knew. Documenting Electric Utilities' Early Knowledge and Ongoing Deception on Climate Change from 1968-2017. Energy and Policy Institute. Available online at: www.eenews.net/assets/2017/07/25/document_gw_08.pdf

Baatz, C. (2016). Can we have it both ways? On potential trade-offs between mitigation and solar radiation management. Environ. Val. 25, 29-49. doi: 10.3197/096327115X14497392134847

Baatz, C., and Ott, K. (2016). "Why aggressive mitigation must be part of any pathway," in Climate Justice and Geoengineering, ed C. Preston (London: Rownan \& Littlefield), 93-108.

Baatz, C., and Ott, K. (2017). "In defense of emissions egalitarianism?" in Climate justice and Historical Emissions, eds L. Meyer and P. Sanklecha (Cambridge: University Press), 165-197.

Bellamy, R., Chilvers, J., and Vaughan, N. (2016). Deliberative mapping of options for tackling climate change: citizens and specialists 'open up' appraisals of geoengineering. Public Underst. Sci. 25, 269-286. doi: $10.1177 / 0963662514548628$

Betz, G., and Cacean, S. (2012). Ethical Aspects of Climate Engineering. Karlsruhe: KIT Scientific Publishing.

Bonsch, M., Humpenöder, F., Popp, A., Bodirsky, B., Dietrich, J. P., Rolinski, S., et al. (2016). Trade-offs between land and water requirements for large-scale bioenergy production. Bioenergy 8, 11-24. doi: 10.1111/gcbb.12226

Bourguignon, F. (2012). La Mondalisation de l'Inégalité. Paris: Éditions du Seuil.

Braudel, F. (1985). La Dynamique du Capitalism. Paris: Éditions Arthaud.

Cafaro, P. (2015). How Many is Too Many? Chicago, IL: University Press.

Cairns, R. (2014). Will Solar Radiation Management enhance global security in a changing climate? Climate Geoengineering Governance Working Papers 016. Sussex: Oxford.

Carter, A. (1993). "Towards a green political theory," in The Politics of Nature, eds A. Dobson and P. Lucardie (London: Routledge), 39-62.

Carter, A. (2004). Some theoretical foundations for radical green politics. Environ. Val. 13, 305-328. doi: 10.3197/096327104323312707

Chavez, A. E. (2014). Exclusive Rights to Saving the Planet: the Patenting of Geoengineering Inventions. Northwestern Journal of Technology and Intellectual Property Forthcoming, Available online at: SSRN: http://ssrn.com/ abstract $=2430456$.

Chitnis, M., Sorrell, S., Druckman, A., Firth, S. K.,and Jackson, T. (2013). Turning lights into flights: estimating direct and indirect rebound effects for UK households'. Energy Policy 55, 234-250. doi: 10.1016/j.enpol.2012.12.008

Cohen, G. A. (1989). On the currency of egalitarian justice. Ethics 99, 906-944. doi: $10.1086 / 293126$

Creutzig, F. (2016). Economic and ecological views on climate mitigation with bioenergy and negative emissions. Bioenergy 8, 4-10. doi: 10.1111/gcbb. 12235

Crutzen, P. (2006). Albedo enhancement by stratospheric sulfur injections: a contribution to resolve a political dilemma? Clim. Change 77, 211-220. doi: 10.1007/s10584-006-9101-y

Dykema, J. A., Keith, D W., Anderson, J. G., and Weisenstein, D. (2014). Stratospheric controlled perturbation experiment: a small-scale experiment to improve understanding of the risks of solar geoengineering. Philos. Trans. R. Soc. 372, 1-21. doi: 10.1098/rsta.2014.0059

Economy, E. C. (2004). The River Runs Black. The Environmental Challenge to China's Future. Ithaca, NY: Cornell University Press.

\section{ACKNOWLEDGMENTS}

The author is indebted to Christian Baatz, Yogi Hendlin, Lara Meyer, David Morrow, Frederike Neuber, and three reviewers for helpful comments. The article emerged from the Priority Program 1689 of the German Research Foundation (DFG): Climate Engineering. Risks, Challenges, Opportunities. See www. spp-climate-engineering.de. The usual disclaimer applies.

Egan-Krieger, T. (2014). Die Illusion Wertfreier Ökonomie. Eine Untersuchung der Normativität Heterodoxer Theorien. Frankfurt, NY: Campus.

Engelke, P., and Chiu, D. (2016). Climate Change and US National Security. Atlantic Council.

Environmental Protection Agency (EPA) (2018). Inventory of U.S. Greenhouse Gas Emissions and Sinks 1990-2016. EPA-430-R-18-003.

Ferraro, A. J. (2013). Atmospheric Responses to Geoengineering in the Stratosphere. Reading: University of Reading.

Fleming, J. (2010). Fixing the Sky. NewYork, NY: Columbia University Press.

Galbraith, J. K. (1967). The New Industrial State. Princeton, NJ: Princeton University Press.

Gardiner, S. (2010). "Is 'Arming the Future' with geoengineering really the lesser evil?" in Climate Ethics. Essential Readings, eds S. Gardiner and S. Caney, D. Jamieson, H. Shue (Oxford: University Press), 284-312.

Gardiner, S. (2012). "Are we the scum of the earth? Climate change, geoengineering, and humanity's challenge," in Ethical Adaption to Climate Change. Human Virtues of the Future, eds A. Thompson and J. BendikKeymer(Cambridge, MA: MIT Press), 241-260.

Grüne-Yanoff, T. (2016). "Framing," in The Argumentative Turn in Policy Analysis, eds S. O. Hansson and G. H. Hadorn (Berlin; New York, NY: Springer), 189-215.

Gunderson, R., Petersen, B., and Stuart, D. (2018). A critical examination of geoengineering: economic and technological rationality in social context. Sustainability 10, 296. doi: 10.3390/su10010269

Hale, B. (2012). "The world that would have been: moral hazard arguments against geoengineering," in Engineering the Climate, ed C. Preston (Lexington, KY: Lanham), 113-132.

Hamilton, C. (2014). Geoengineering and the politics of science. Bull. Atomic Sci. 70, 17-26. doi: 10.1177/0096340214531173

Hampicke, U. (2011). Climate change economics and discounted utilitarianism. Ecol. Econo. 72, 45-52. doi: 10.1016/j.ecolecon.2011.08.028

Hausman, D. M. (2012). Preference, Value, Choice, and Welfare. Cambridge: University Press.

Hodgson, G. (2001). Economy as a Moral Science. Berlin: Springer.

Horton, J., and Keith, D. (2016). "Solar geoengineering and obligations to the global poor," in Climate Justice and Geoengineering, ed C. Preston (London: Rowman \& Littlefields), 79-93.

Huttunen, S., Skytén, E., and Hildén, M. (2015). Emerging policy perspectives on geoengineering: an international comparison. Anthrop. Rev. 2, 14-32. doi: $10.1177 / 2053019614557958$

IPCC (2013). "Climate change 2013: The Physical Science Basis," in Contribution of Working Group I to the Fifth Assessment Report of the Intergovernmental Panel on Climate Change. eds T. F. Stocker, D. Qin, G. K. Plattner, M. Tignor, S.K. Allen, J. Boschung, A. Nauels, Y. Xia, V. Bex, and P. M. Midgley (Cambridge; NewYork, NY: Cambridge University Press).

Jamieson, D. (2014). Reason in a Dark Time. Oxford: Oxford University Press.

Jänicke, M. (2013). "Accelerators of Global Energy Transition: Horizontal and Vertical Reinforcement in Multi-Level Climate Governance," in IASS Working Paper, (Potsdam: IASS).

Kearnes, L. (2007). "Cooking the truth," in Ecospirit. Religions and Philosophies for the Earth, eds L. Kearnes and C. Keller (New York, NY: Fordham University Press), 97-124.

Keith, D. (2000). Geoengineering the climate: history and prospect. Ann. Rev. Energy Environ. 25, 245-284. doi: 10.1146/annurev.energy.25.1.245

Keith, D. (2013). A. Case for Climate Engineering. Boston, MA: MIT Books. 
Klepper, G., and Rickels, W. (2012). The real economics of climate engineering. Econo. Res. Int. 2012:316564. doi: 10.1155/2012/316564

Lin, A. C. (2013). Does geoengineering present a moral hazard? Ecol. Law Quart. 40, 673-712. Available online at: https://law.ucdavis.edu/faculty/lin/files/ELQ. MoralHazard.pdf

Lipson, L. (1960). The Great Issues of Politics, 2nd Edn. Englewood Cliffs, NJ: Prentice Hall.

MacMartin, D. G., Ricke, K. L., and Keith, D. W. (2018). Solar geoengineering as part of an overall strategy for meeting the $1.5^{\circ} \mathrm{C}$ Paris target. Philos. Trans. $R$. Soc. 376:20160454. doi: 10.1098/rsta.2016.0454

Merk, C., Pönitzsch, G., Braun, C., Rehdanz, K., Schmidt, U. (2015). Exploring public perceptions of stratospheric sulfate injection. Clim. Change 130, 299-312. doi: 10.1007/s10584-014-1317-7

Merk, C., Pönitzsch, G., Rehdanz, K. (2016). Knowledge about aerosol injection does not reduce individual mitigation efforts. Environ. Res. Lett. 11:054009. doi: 10.1088/1748-9326/11/5/054009

Meyer, A. (2000). Contraction \& Convergence: The Global Solution to Climate Change, Schumacher Briefing 5. Cambridge: Green Books for the Schumacher Society.

Milanovic, B. (2016). Global Inequality. Cambridge, MA; London: Belknap Press of Harvard.Ministère de la Transition Ecologique et Solidaire (2017). Climate Plan. Paris.

Moellendorf, D. (2014). The Moral Challenge of Dangerous Climate Change. Cambridge: University Press.

Mommsen, W. (1974). "'Verstehen' und 'Idealtypus'." Zur Methodologie einer historischen Sozialwissenschaft," in Max Weber. Gesellschaft, Politik und Geschichte, ed W. Mommsen (Frankfurt: Suhrkamp), 208-232.

Mooney, C. (2016). Rex Tillerson's View of Climate Change: it's Just an Engineering Problem. The Washington Post 12/14/2016.

Moore, J., Chen, Y., Cui, X., Yuan, W., Dong, W., Gao, Y., Shi, P., et al. (2016). Will China be the first to initiate climate engineering? Earth Future 4, 588-595. doi: 10.1002/2016EF000402

Moriyama, R., Sugiyama, M., Kurosawa, A., Masuda, K., Tsuzuki, K., and Ishimoto, Y. (2016). The cost of stratospheric climate engineering revisited. Mitig. Adap. Strat Glob. Change 22, 207-1228. doi: 10.1007/s11027-016-9723-y.

Morrow, D. (2014). Ethical aspects of the mitigation obstruction argument against climate engineering research. Philos. Trans. R. Soc. A 372, 1-14. doi: $10.1098 /$ rsta.2014.0062

Morrow, D., and Svoboda, T. (2016). Geoengineering and non-ideal theory. Public Affairs Quart. 30, 83-102.

Münch, R. (1998). Globale Dynamik, Lokale Lebenswelten. Frankfurt: Suhrkamp.

Muraca, B., and Neuber, F. (2017). Viable and convivial technologies: considerations on climate engineering from a degrowth perspective. J. Clean. Product. doi: 10.1016/j.jclepro.2017.04.159

Neuber, F. (2017). Buying Time with Climate Engineering. Ph.D. thesis, University of Karlsruhe.

Orcutt, M. (2017). Why this Geoengineering Pioneer's Worst Nightmare is a Trump Tweet. MIT Technology Review.

Oreskes, N., and Conway, E. (2011). Merchants of Doubt: How a Handful Scientists Obscured the Truth on Issues from Tobacco Smoking to Global Warming. Chicago, IL: University of Chicago Press.

Ott, K. (2011). Domains of climate ethics. Jahrbuch für Wissenschaft und Ethik 16, 95-114.

Ott, K. (2012a). "Might solar radiation management constitute a dilemma?" in Engineering the Climate. The Ethics of Solar Radiaton Management, ed C. Preston (Lexington, KY: Lexington Press), 33-43.

Ott, K. (2012b). Variants of de-growth and deliberative democracy: a habermasian proposal. Futures 44, 571-581. doi: 10.1016/j.futures.2012.03.018

Ott, K. (2014). Institutionalizing strong sustainability: a rawlsian perspective. Sustainability 6, 894-912. doi: 10.3390/su6020894

Pfister, C. (2010). "The '1950s Syndrome' and the transition from a slow-going to a rapid loss of global sustainability," in The Turning Points of Environmental History, ed F. Uekötter (Pittsburgh, PA: University Press), 91-118.

Preston, C. J. (Ed.) (2012). Engineering the Climate, The Ethics of Solar Radiation Management. Lanham, MD: Lexington Books.

Preston, C. L. (Ed.) (2016). Climate Justice and Geoengineering. London: Rowman \& Littlefield.
Quaas, M., Quaas, J., Rickels, W., and Boucher, O. (2017). Are there reasons against open-ended research into solar radiation management? A model of intergenerational decision-making under uncertainty. J. Environ. Econom. Manage. 84, 1-17. doi: 10.1016/j.jeem.2017.02.002

Randall, A. (2002). "Benefit-cost considerations should be decisive when there is nothing more important at stake," in Economics, Ethics, and Environmental Policy. Contested Choices, eds S. W. Bromley and J. Paavola (Oxford: Blackwell), 53-68.

Rawls, J. (1971). A. Theory of Justice. Oxford: Oxford University Press.

Reynolds, J., Parker, A., and Irvine, P. (2016). Five solar geoengineering tropes that have outstayed their welcome. Earth Future 4, 562-568. doi: 10.1002/2016EF000416

Rickels, W., Klepper, G., Dovern, J., Betz, G., Brachatzek, N., Cacean, S., et al. (2011). Large-Scale Intentional Interventions into the Climate System? Assessing the Climate Engineering Debate. Scoping report conducted on behalf of the German Federal Ministry of Education and Research (BMBF). Kiel: Kiel Earth Institute.

Schröder, M., Clausen, M., Grunwald, A., Hense, A., Klepper, G., Lingner, S., et al. (2002). Klimavorhersage und Klimavorsorge. Berlin; Heidelberg: Springer.

Schumpeter, J. (1942). Capitalism, Socialism and Democracy. New York, NY: Harper.

Sen, A. (1999). Development as Freedom. New York, NY: Knopf.

Shue, H. (2014). Climate Justice. Oxford: University Press.

Sikka, T. (2012). A critical discourse analysis of geoengineering advocacy. Critic. Dis. Stud. 9, 163-175. doi: 10.1080/17405904.2012.656377

Sikka, T. (2013). "An analysis of the connection between climate change, technological solutions and potential disaster management: the contribution of geoengineering research," in Climate Change and Disaster Management, ed W. L. Filho (Berlin: Springer), 535-551.

Sillmann, J., Lenton, T., Levermann, A., Ott, K., Hulme, M., Benduhn, F., et al. (2015). Climate emergencies do not justify engineering the climate. Nat. Clim. Change 5, 291-292. doi: 10.1038/nclimate2539

Smith, L. (2017). Statement from Chairman. Committee on Science, Space, \& Technology.

Smith, L. (2018). Technology Advances Civilization. Bureaucrats Do Not. The Daily Caller.

SRU (Environmental Advisory Board for Germany) (2002). Environmental Report 2002. Towards a New Leading Role. Berlin: German Advisory Council on the Environment.

Stern, N. (2007). The Economics of Climate Change. Cambridge: Cambridge University Press.

Svoboda, T. (2016). Aerosol geoengineering deployment and fairness. Environ. Val. 25, 51-68. doi: 10.3197/096327115X14497392134883

Takebayashi, T. (2003). Die Entstehung der Kapitalismustheorie in der Gründungsphase der deutschen Soziologie. Berlin: Duncker \& Humblot.

WBGU (2011). World in Transition: A Social Contract for Sustainability. Berlin: German Advisory Council on Global Change.

Weber, M. [1905]/(2001). The Protestant Ethic and the Spirit of Capitalism. London, New York, NY: Routledge.

Wolin, S. (2008). Democracy Inc. - Managed Democracy and the Specter of Inverted Totalitarianism. Princeton, NJ: University Press.

Xueliang, G. (2009). Advances in weather modification from 1997 to 2007 in China. Adv. Atmosph. Sci. 26, 240-252. doi: 10.1007/s00376-009-0240-8

Zhang, Z., Moore, J. C., Huisingh, D., and Zhao, Y. (2015). Review of geoengineering approaches to mitigate climate change. J. Clean. Product. 103, 898-907. doi: 10.1016/j.jclepro.2014.09.076

Conflict of Interest Statement: The author declares that the research was conducted in the absence of any commercial or financial relationships that could be construed as a potential conflict of interest.

Copyright $\odot 2018$ Ott. This is an open-access article distributed under the terms of the Creative Commons Attribution License (CC BY). The use, distribution or reproduction in other forums is permitted, provided the original author(s) and the copyright owner are credited and that the original publication in this journal is cited, in accordance with accepted academic practice. No use, distribution or reproduction is permitted which does not comply with these terms. 